\title{
The relationship between Impression Management and Organizational Politics in the Egyptian Travel Agencies
}

\author{
Marwa Fawzy \\ Associate Professor \\ Tourism Studies Department \\ University of Sadat City
}

\author{
Toka Mahrous \\ Associate Professor \\ Tourism Studies Department \\ University of Sadat City
}

\begin{abstract}
This paper attempts to understand the level of perceived organizational politics POP and impression management IM among employees and assessing their mutual relationship in travel agencies. To attain this goal, a total number of 253 usable questionnaires were collected from employees in travel agencies. Correlation and regression analysis were conducted to find out the relationship between the study's variables. The results showed a positive correlation between IM behavior and POP. The results also indicated that $42 \%$ of IM was dependent on POP. Moreover, the results suggested that not all forms of IM are equally correlated to POP. For instance, it can be concluded that individuals who take part in supervisor-focused tactics of IM were more affected by POP than the ones who participate in job-focused tactics.
\end{abstract}

Keywords: impression management, perceptions of politics, travel agencies

\section{Introduction}

Goffman introduced Impression management (IM) theory in 1950s as a model of social life and sociology theory based on two key players: an actor and an audience who interact with actors within their workplace (Drory \& Zaidman, 2007). Bozeman \& $\operatorname{Kacmar}(1997)$ and Bolino et al., (2008) described this relation as efforts by an individual or actor who engages in IM behavior to change, protect or create an image held by an audience. From the individual point of view, IM can be referred to as self-presentation since individuals attempt to control their images to the audience. Keeping in mind that the aim for the actor here is to control an impression on the audience, one can easily understand that IM behaviors are inevitable and have vital importance in organizations. There can be many reasons to engage in IM however, Schniederjans et al. (2013) suggested that the main motives of these behaviors are maximizing expected rewards and/or reducing expected punishments (Yilmaz,2014). Moreover, Drory \& Zaidman (2007) categorized IM behaviors into two main categories: assertive strategies, which an actor uses to create personality, and defensive or protective strategies, which are designed to fix damaged identities.

Impression Management (IM) is the study of individuals attempt to deal with or organize the perceptions others form of them (Bozeman \& Kacmar, 1997; Drory \& Zaidman, 2007). IM aims to guide opinions or impressions under control of information in an individual or social situation (Drory \& Zaidman, 2007). 
Furthermore, IM theory can be practiced at a macro organizational level and also being used in an individual setting (Avery \& McKay, 2006; Mohamed \& Gardner, 2004). Organizations use IM tactics to manage their image of the organization and develop a positive image with audience outside the organization(Terrell,Kwok, 2011).

Consequently, Hochwarter et al. (2003) suggested that the organizational politics (OP) at work can shape employees' behavior in different ways ranging from very beneficial to extremely harmful. Therefore, organizational politics have a great influence on business outcomes. For that reason, (OP) should be determined in terms of reality and, therefore, perception of politics (POP) should also be considered as a measure of OP in academic research. Many researchers have given importance to the examination of OP phenomenon and its definition and thier negative implication (Poon, 2003; Andrewset al., 2003; Vigoda, 2000). Kacmar, et al. (1999), Vigoda (2000) and Poon (2004) mentioned that most researchers suggested negative outcomes and impacts of (POP) particularly in complex business environments. Furthermore, studies in POP explained that there was a strong positive relationship between POP and turnover intentions and a negative relationship between POP and job satisfaction (Kacmar, et al., 1999). Thus, the examination of POP is very important to illustrate OP and this explains why POP affects individuals' reactions (Aryee et al.,2004).

Moreover, The purpose of this paper is to assess the level of perceived organizational politics POP and impression management IM among employees in travel agencies, and find out their mutual relationship.

\subsection{Impression Management}

Impression management refers to the activity of prearranging information to steer others' opinions in the service of individuals or social goals. Although people can handle impressions of anything, people most commonly manage the impressions others form of themselves, a part of impression management that is often termed self-presentation, such as public relations expert representing a company (Schlenker \& Pontari, 2000). The definition of impression management has been indicated to an attempt by individuals to control the image they illustrate in social relationships through restricting information available to others. This definition contains two parties: the actor who introducing the information; and the target audience, the one receiving the information (Goffman, 1959). The vast majority of studies have examined only the actor side (Doherty\&Schenker, 1991; Kowalski\&Leary,1990; Tice, 1991).

Bozeman and Kacmar (1997) have categorized different frameworks for IM such as direct-indirect tactics, or assertive-defensive tactics. However, Wayne and Ferris's (1990) conceptualization of IM is probably the most broadly used one in practical work. Wayne and Ferris (1990) classified IM strategies in three parts named as supervisor-focused, self-focused and job focused strategies. Supervisor-focused tactics can be summarized as ingratiatory or favor- 
rendering behaviors of employees. Individuals who employ such tactics may compliment and praise their supervisors and they try to be seen as helpful, considerate, and kind. Secondly, self-focused tactics involve behaviors of employee that are appeared to make individuals seem polite, hardworking and dedicated employees. Employees of these tactics tend to work hard when others are looking. Finally, job-focused tactics involve self-promotive behaviors and are designed to make employees appear more skilled at their job. On the other hand, individuals do not always use the same tactic in every situation as well as different individuals may probably use different strategies when faced with similar situations (Yilmaz, 2014).

Many research efforts have been focused on the relationship between individuals and organizations and how they form and manage their impressions to the target audience. From these research efforts Bolino et al., (2008) reviewed special articles since 1988 about IM with the attempt to offer recommendations for future studies of IM in organizations. They revealed that research on IM in the individual level dealt with how job candidates or employees might manage information to improve their images at work. Terrell and Kwok, (2011) suggested that individuals manage and handle selective information to introduce positive image with high level of responsibility and clearness. In general, impressions management should be motivated to obtain a desirable outcome such as a job offer. Moreover, IM at the organizational level is focused on five areas that include: (a) the use of IM tactics defensively, (b) how organizations use IM tactics in a firm way to increase acceptance of a controversial decision, (c) how organizations use tactics to build image or achieve a goal, (d) the role of audience; and (e) what offense tactics an organization used to damage the reputation of their competitors. The direct result of IM tactics on work outcomes such as career achievement (Judge \& Bretz, 1994; Judge, et al., 1995), performance evaluation (Bolino, et al., 2006), job performance (Cheng, et al, 2013), performance rating (Wayne \& Liden, 1995) and selection interviews (Wade \& Kinicki, 1997).

\subsection{Organizational Politics}

Organizational politics (OP)is defined as a significant dimension of organizational functioning. OP is described as behaviors tactically designed to maximize self-interests and this description reflects a generally negative image of OP in the eye of most individuals. OP reflects illegal force-relations between organization's members. Therefore, employees find politics as an unfair and unreasonable behavior (Yilmaz, 2014).

In political organizations relationships, encouragement, and other less objective elements may be tied to work performance (Kacmar \& Ferris, 1991) instead of rewards. Since perceptions of politics are connected to vague reward structures, in organizational political environment, staff may not have confidence that their skills will recognize, or that valuable rewards will be distributed according to employee behavior at work (Cropanzano et al., 1997). Consequently, high perceptions of organizations politics are probable to be connected to low 
expectancies because of the full effort-reward relationship that individuals fail to see. On contrary, in an environment perceived as being low in politics, the relationship between behavior and rewards is clear and is likely to be relatively high, leading employees to be more motivated to adjust their behavior to increase their probability of gaining reward (Zivnuska et al., 2004).

Therefore, political actions in organizations called political games it can take many forms. Such as Mintzberg's order, he has categorized thirteen behaviors as expertise, alliance building, rival camps, and strategic candidates etc. Moreover, Allen et al., (1979) recommended eight different categories for political behaviors that can be examined under such as; (1) blaming or attacking others, (2) use of information, (3) impression management, (4) support building for ideas, (5) ingratiation, (6) power coalitions, (7) associating with the influential and (8) creating obligations. Through this categorization, organizational politics tactics can be easily understood that content both reactive and proactive behaviors. The tactics can be reactive, proactive or both at the same time depending upon the situation. There is no doubt that impression management is sometimes considered a kind of political behavior in studies. This tactic is mainly proactive and it is especially intended to promote self-interest. Furthermore, image-building tactic is taking into consideration the good ideas of someone else. However, impression management can also take account of general appearance, planning for success, creating the appearance or developing a reputation. (Yilmaz, 2014).

\subsection{The relationship between Impression Management and organizational politics}

In general, some negative perceptions about employment conditions and practices haunting tourism and especially hospitality operations because of low incomes, poor career structures, seasonality, high labor-turnovers, and shift systems. Furthermore, it is extensively recognized and accepted that the achievements of success and progress in tourism depends mainly on employees and human resources. In other words, how these employees are recruited, managed, trained, motivated and/or rewarded through their career development, play a vital role in every organization in the tourism industry. The role that employees play in tourism requires more attention especially on issues related to organizational behavior. Although the number of researches conducted in tourism industry has increased in the past two decades, there are still some niches in the related literature within the industry, which is characterized by diversity of organizations and employees (Yilmaz, 2014).

Expectancy theory provides the view that environmental perceptions will change an individual's tendency to modify his or her behavior. It is very important to focus on clarifying the nature of perceptions of organizational politics and impression management, and their combined effects on performance. This challenge is overcome by offering expectancy theory as a bridge between them(Zivnuska et al., 2004). 
Chang et al. (2009) described organizational climates as social marketplaces where individuals participate in transaction to gain favorable rewards. At this point Gardner \& Martinko (1988) stated that employees try to manage their images to the others and engage in impression management (IM) behaviors to either increase expected rewards or reduce expected punishments. Both OP and IM have a negative meaning in the literature, since most IM behaviors are described as thoughts that stem from personal or employees' goals. IM could be characterized as a process through which individuals look to affect others to accomplish a particular objective(Bozeman \& Kacmar, 1997; Bolino \& Turnley, 1999). However, Ellis et al. (2002) suggested that IM behaviors are consisted of verbal statements and nonverbal behaviors. Furthermore, Wayne \& Liden (1995), Bolino \& Turnley (2003), Zivnuska, et al., (2004) and Bolino, et al., (2006) suggested that there is a direct relationship between IM behaviors and performance appraisals. In the same way, Judge \& Bretz (1994) and Judge, et al., (1995) explained the outcome of IM and political power behavior on the success of the organization. These studies confirmed that employees manage IM behaviors in order to achieve their goals. Therefore, OP could also influence IM behaviors in work environments when the employee promoted from grade to another.

As a result, it is vital to explore the relationship between OP and IM behaviors and their effects, as it is probable that organizational environment will always be loaded with politics and political games. Undoubtedly, when making a comparison between tourism industry and other industries, tourism industry concentrates more on behaviors and attitudes of employees. Consequently, all tourism organizations need to manage their policies to reduce political practices (Yilmaz, 2014).

\section{Methodology}

This study aimed at identifying the level of perceived organizational politics and impression management of employees and assessing the relationship between perception of organizational politics and impression management behaviors in travel agencies.

\subsection{Respondents}

The target populations of this study are the employees in travel agencies category "A " in Egypt. This category of travel companies was chosen as they are supposed to be more knowledgeable and to have a basic understanding and relation with the topics of research in order to obtain significant data. Sample was randomly chosen. The survey was administered to 350 employees. The mail survey was the main form of data collection. Data collection was carried out during the period from Jan 2016 to May 2016. There were 262 responses received, indicating an estimated response rate of 75 percent. However, only 253 of the questionnaires were valid. 


\subsection{Instrument}

The data collecting method of the study was questionnaire. A pilot study was conducted to test the questionnaire validity. Reliability analysis on item-scale was conducted. In the questionnaire, Cronbach's alpha of the study two measures were above 0.70. The questionnaire was prepared based on the Likert's 5 scale model. The questionnaire comprises of three sections. Section 1 consists of 13 inquiries to measure the Perception of Politics (POP) of employees' with five point scale ranging from extremely disagree(1) to extremely agree(5). The higher score of the five point Likert scale means the higher perceived organizational politics. Section 2 consists of 16 questions to measure the Impression Management (IM) with five point scale ranging from extremely disagree(1) to extremely agree(5). The higher score of the five point Likert scale means the higher level of impression management. Section 3 is the respondents profile.

\subsection{Measures}

\subsubsection{Perceptions of Organizational Politics}

Perceptions of Organizational Politics were measured using revised items from Kacmar and Ferris' (1991) 12-items Perceptions of Organizational Politics Scale (POPS), Ferris and Kacmar's (1992) 31-item POPS, and Kacmar and Carlson's (1997) fifteen item POPS. Based on a five-point scale ranging from extremely disagree (1) to extremely agree (5). Example items include "People in this organization attempt to build themselves up by tearing others down." ," Employees are encouraged to speak out frankly even when they are critical of well-established ideas " and " Since I have worked in this department, I have never seen the pay and promotion policies applied politically ". Higher scores indicated greater levels of perceptions of organizational politics. The Cronbach alpha reliability for the scale in this study was 0.759

\subsubsection{Impression management}

In order to evaluate impression management from subordinates, the researchers used sixteen-item assertive impression management scale developed by Yilmaz (2014). This items are divided into three group namely; supervisor-focused behaviors, self-focused behaviors and job-focused behaviors. Based on a fivepoint scale extremely disagree (1) to extremely agree (5). Example items include "Do personal favors for my supervisor" " "Work hard when you know the results will be seen by your supervisor" and "Try to take responsibility for positive events, even when I am not solely responsible". Higher scores indicated greater levels of impression management. The Cronbach Alpha reliability for the scale in this study was 0.845

\subsection{Data analysis}

Data was analyzed using SPSS version 16 software package. The suitable tools were used to test the hypotheses and find the reliability. Cronbach's alpha was used to test the reliability of the data, the mean and standard deviation have been calculated to classify the sets and determine how homogenous or 
discrepant (inconsistent) the sample is, regarding all research variables. A correlation analysis was then conducted to find out the relationship between perception of organizational politics and impression management behaviors in travel agencies. Moreover, regression analysis was conducted to measure the effect of organizational politics on impression management.

\section{Results}

\section{Respondent Profile}

Respondents' demographic data was analyzed by descriptive statistics using the SPSS 16. Table 1 shows the demographic profile of respondents. Female represents $(21.8 \%)$ while male represents 78.2 of respondents. Most respondents were relatively young; $(73 \%)$ of them were under the age of 41 , while $(42.6 \%)$ of them fall into the age category of 24-30. In terms of work experience, $(20.2 \%)$ respondents were less than a one year period, nearly half respondents $(47 \%)$ fall into the range from a one year to five years, $(25.7 \%)$ of the respondents have experience ranged from six to ten years, while the work experience of $(7 \%)$ of respondents were more than ten years.

Regarding the respondents' level of education, (81\%) of them were College Graduate, (9.8received postgraduate degree. Only 9\% received a diploma.

Table 1: The Profile of the Respondents

\begin{tabular}{|l|c|c|}
\hline \multicolumn{1}{|c|}{ Variable } & Freq. & \% \\
\hline Gender & & \\
\hline$\square$ Female & 54 & 21.8 \\
\hline$\square$ Male & 189 & 78.2 \\
\hline Age & 108 & 42.6 \\
\hline$\square 24-30$ & 77 & 30.4 \\
\hline$\square 31-40$ & 36 & 14.2 \\
\hline$\square 41-50$ & 32 & 12.6 \\
\hline$\square$ more than 50 & & \\
\hline Work experience & 51 & 20.2 \\
\hline$\square$ Less than 1 year & 119 & 47 \\
\hline$\square 1-5$ years & 65 & 25.7 \\
\hline$\square 6-10$ years & 11 & 4 \\
\hline$\square 11-15$ years & 7 & 3 \\
\hline$\square 16$ years and above & & \\
\hline Education & 30 & 9 \\
\hline$\square$ Diploma & 205 & 81 \\
\hline$\square$ College Graduate & 25 & 9.8 \\
\hline$\square$ Postgraduate Degree (MSc, PhD... etc.) &
\end{tabular}

The reliability of the scales was tested by calculating their coefficient alpha (Cronbach's alphas $\alpha$ ) to determine the degree of internal consistency between the measurements used in the study. Cronbach's alpha should meet the recommended significance of 0.70 or higher ((Nunnaly, 1978). A reliability analysis revealed Cronbach's alphas of 0.845 for the Perception of Politics (POP), 0.759for the Impression Management (IM)indicating acceptable reliability coefficients and a good indication of construct reliability. 
Table (2): The measuring constructs reliability

\begin{tabular}{|c|l|c|}
\hline $\mathbf{N}$ & \multicolumn{1}{|c|}{ Construct } & $\begin{array}{c}\text { Cronbach's } \\
\text { Alpha }\end{array}$ \\
\hline $\mathbf{1}$ & Perception of Politics (POP) & $\mathbf{0 . 8 4 5}$ \\
\hline $\mathbf{2}$ & Impression Management (IM) & $\mathbf{0 . 7 5 9}$ \\
\hline
\end{tabular}

The mean and standard deviation have been calculated to find out how homogenous or discrepant the sample is. The mean value for the perception of politics was ranged from 2.91 to 4.34 and the standard deviation was ranged from 0.67 to 1.98 . Moreover, the mean value for impression management was ranged from 1.9 to 4.54 and the standard deviation was ranged from 0.34 to 1.96, as shown in table 3.

Table (3) Mean and Standard Deviation for the study variables

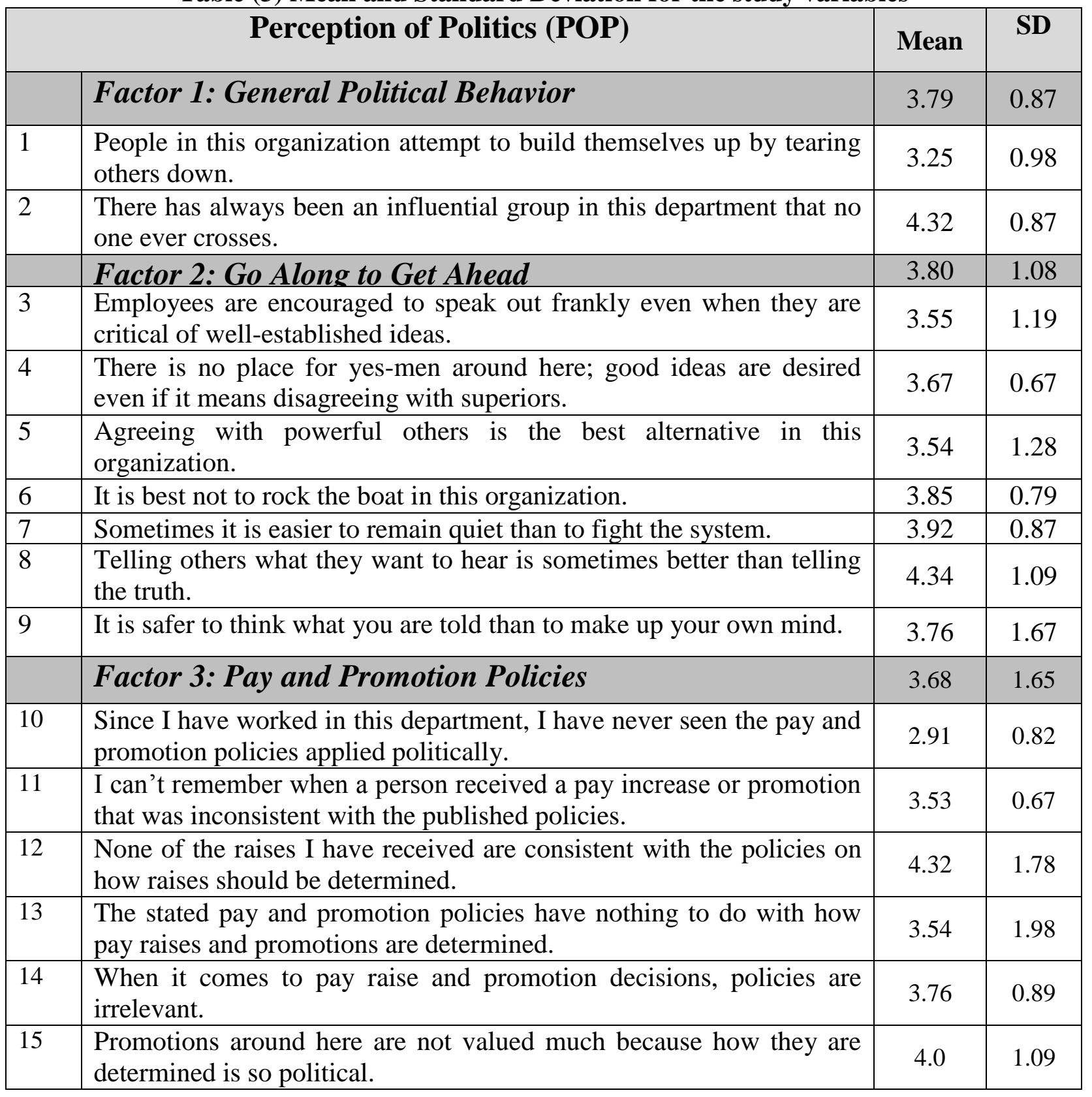




\begin{tabular}{|c|c|c|c|}
\hline \multicolumn{2}{|r|}{ Impression Management (IM) } & \multirow{2}{*}{$\begin{array}{c}\text { Mean } \\
3.27\end{array}$} & \multirow{2}{*}{$\begin{array}{c}\text { SD } \\
0.88\end{array}$} \\
\hline & 1-Supervisor-focused behaviors & & \\
\hline 1 & Do personal favors for my supervisor & 3.0 & 0.56 \\
\hline 2 & Take an interest in my immediate supervisor's personal life & 2.53 & 1.43 \\
\hline 3 & Praise my immediate supervisor on his/her accomplishments & 2.98 & 0.34 \\
\hline 4 & $\begin{array}{l}\text { Offer to do something for my supervisor which I was not required to } \\
\text { do; that is, I did it as a personal favor for him/her }\end{array}$ & 3.80 & 0.85 \\
\hline \multirow[t]{2}{*}{5} & Compliment my immediate supervisor on his/her dress or appearance & 4.05 & 1.23 \\
\hline & 2-Self-focused behaviors & 4.37 & 0.99 \\
\hline 1 & Try to be polite when interacting with your supervisor & 4.52 & 1.01 \\
\hline 2 & Try to be a friendly person when interacting with your supervisor & 4.54 & 0.67 \\
\hline 3 & $\begin{array}{l}\text { Try to act as a 'model' employee by, for example, never taking longer } \\
\text { than the established time for lunch }\end{array}$ & 4.25 & 1.92 \\
\hline \multirow[t]{2}{*}{4} & Work hard when you know the results will be seen by your supervisor & 4.17 & 0.34 \\
\hline & 3-Job-focused behaviors & 3.31 & 1.11 \\
\hline 1 & $\begin{array}{l}\text { Try to make a positive event that I am responsible for appear better } \\
\text { than it actually is }\end{array}$ & 3.00 & 1.12 \\
\hline 2 & Play up the value of a positive event that I have taken credit for & 4.50 & 0.56 \\
\hline 3 & $\begin{array}{l}\text { Try to take responsibility for positive events, even when I am not solely } \\
\text { responsible }\end{array}$ & 3.87 & 0.72 \\
\hline 4 & $\begin{array}{l}\text { Try to make a negative event that I am responsible for not appear as } \\
\text { severe as it actually is to my supervisor }\end{array}$ & 3.21 & 1.76 \\
\hline 5 & Arrive at work early in order to look good in front of my supervisor & 4.00 & 1.96 \\
\hline 6 & $\begin{array}{l}\text { Agree with my supervisor's major opinions outwardly even when I } \\
\text { disagree inwardly }\end{array}$ & 2.58 & 0.89 \\
\hline 7 & $\begin{array}{l}\text { Work late at the office so that my supervisor will see my working late } \\
\text { and think I am a hard worker }\end{array}$ & 1.98 & 0.76 \\
\hline
\end{tabular}

Results of t test, as shown in table 4, indicated that the gender has a significant effect on perceiving POP and IM; male employees perceived organizational politics more than female $(\mathrm{t}=0.327, \mathrm{p}$ value $=0.001)$ with the mean difference of 0.553. Similarly, male employees perceived impression management more than female $(t=0.973$, $p$ value $=0.004)$, the mean difference is 0.724 .

Table (4) the Differences in Participants' POP and IM in Relation to Gender

\begin{tabular}{|c|c|c|c|c|c|c|}
\hline variable & Gender & $\mathrm{N}$ & Mean & SD & t & Sig \\
\hline \multirow{2}{*}{ POP } & Female & 54 & 3.460 & 1.453 & .327 & 0.001 \\
\cline { 2 - 8 } & Male & 189 & 4.013 & 0.987 & & \\
\hline \multirow{2}{*}{ IM } & Female & 54 & 3.262 & 0.764 & .973 & 0.004 \\
\cline { 2 - 8 } & Male & 189 & 3.986 & 0.567 & & \\
\hline
\end{tabular}

One way ANOVA results showed significant difference between employee's participation in POP and IM in relation to their age, employees who were between 31- 40 years had the highest POP and IM than other age groups $(\mathrm{F}=3.98,4.76 \mathrm{p}$ value $=0.000,0.001)$. 
Table (5) the Differences in Participants' POP and IM in Relation to Age

\begin{tabular}{|c|l|c|c|c|c|c|}
\hline variable & \multicolumn{1}{|c|}{ Age } & $\mathrm{N}$ & mean & SD & F & P \\
\hline \multirow{5}{*}{ POP } & $\square 24-30$ & 108 & 3.74 & 0.945 & & \\
\cline { 2 - 5 } & $\square 31-40$ & 77 & 3.98 & 0.692 & \multirow{3}{*}{3.98} & \multirow{3}{*}{0.000} \\
\cline { 2 - 5 } & $\square 41-50$ & 36 & 3.65 & 1.231 & & \\
\cline { 2 - 5 } & $\square$ more than 50 & 32 & 3.52 & 0.673 & & \\
\hline \multirow{4}{*}{ IM } & $\square 24-30$ & 108 & 3.65 & 1.982 & & \\
\cline { 2 - 5 } & $\square 31-40$ & 77 & 3.87 & 0.849 & \multirow{3}{*}{4.76} & \multirow{3}{*}{0.001} \\
\cline { 2 - 5 } & $\square 41-50$ & 36 & 3.49 & 1.329 & & \\
\cline { 2 - 5 } & $\square$ more than 50 & 32 & 3.61 & 0.791 & & \\
\hline
\end{tabular}

The results indicated that the employees' work experience have a significant effect on perceiving POP and IM ; the employees whose work experience between six and ten years have participated more in IM and POP $(F=2.91,3.65, \mathrm{P}$ value $=0.006,0.013)$.

Table (6) The Differences in Participants' POP and IM in Relation to Work Experience

\begin{tabular}{|c|c|c|c|c|c|c|}
\hline variable & Working experience & $\mathrm{N}$ & mean & SD & $\mathrm{F}$ & $\mathrm{P}$ \\
\hline \multirow{5}{*}{ POP } & $\square$ Less than 1 year & 51 & 3.54 & 0.497 & \multirow{5}{*}{2.91} & \multirow{5}{*}{0.006} \\
\hline & $\square 1-5$ years & 119 & 3.55 & 0.864 & & \\
\hline & $\square 6-10$ years & 65 & 3.98 & 0.972 & & \\
\hline & $\square 11-15$ years & 11 & 3.92 & 1.139 & & \\
\hline & $\square 16$ years and above & 7 & 3.79 & 0.815 & & \\
\hline \multirow{5}{*}{$\mathrm{IM}$} & $\square$ Less than 1 year & 51 & 3.36 & 0.782 & \multirow{5}{*}{3.65} & \multirow{5}{*}{0.013} \\
\hline & $\square 1-5$ years & 119 & 3.78 & 0.927 & & \\
\hline & $\square 6$-10 years & 65 & 3.99 & 0.640 & & \\
\hline & $\square 11-15$ years & 11 & 3.63 & 0.756 & & \\
\hline & $\square 16$ years and above & 7 & 3.54 & 0.238 & & \\
\hline
\end{tabular}

It is obvious from table 7 that there is no significant difference on perceiving POP regarding the respondents' level of education $(\mathrm{F}=4.35, \mathrm{P}$ value $=0.19)$. On the contrary, there is a significant difference on perceiving IM regarding the respondents' level of education $(\mathrm{F}=3.23, \mathrm{P}=0.028)$. Further, summary of means scores showed the extent of significance. Post graduated scored the least and high school scored the highest mean.

Table (7) the Differences in Participants' POP and IM in Relation to Education

\begin{tabular}{|l|l|l|l|l|l|l|}
\hline variable & Education & $\mathrm{N}$ & mean & SD & $\mathrm{F}$ & $\mathrm{P}$ \\
\hline \multirow{5}{*}{ POP } & $\square$ Diploma & 30 & 3.95 & 0.736 & \multirow{3}{*}{4.35} & 0.19 \\
& $\square$ College Graduate & 205 & 3.58 & 0.502 & & \\
\cline { 2 - 6 } & $\square$ Postgraduate Degree (MSc, & 25 & 3.75 & 0.938 & & \\
\hline \multirow{4}{*}{ IM } & $\square$ Diploma & 30 & 3.78 & 0.643 & \multirow{3}{*}{3.23} & 0.028 \\
\cline { 2 - 5 } & $\square$ College Graduate & 205 & 3.76 & 0.794 & & \\
\cline { 2 - 5 } & $\square$ Postgraduate Degree (MSc, & 25 & 3.40 & 0.943 & & \\
\hline
\end{tabular}


A correlation analysis was conducted to find out the relationship between respondents' perception of organizational politics (POP) and impression management (IM) behaviors. The results as shown in (Table 8) indicate that there is a positive correlation between the two variables $(r=0,608$ and $p<0.5)$.

Table (8) Correlations among the Study Variables

\begin{tabular}{|l|l|l|l|l|l|l|l|}
\hline \multicolumn{1}{|c|}{ Variables } & \multicolumn{1}{|c|}{$\mathbf{1}$} & $\mathbf{2}$ & $\mathbf{3}$ & $\mathbf{4}$ & $\mathbf{5}$ & $\mathbf{6}$ & $\mathbf{7}$ \\
\hline $\begin{array}{l}\text { 1. Perception of Organizational } \\
\text { Politics }\end{array}$ & 1 & & & & & & \\
\hline 2-General Political Behavior & $0.851^{*}$ & 1 & & & & & \\
\hline 3-Go Along to Get Ahead & $0.809^{*}$ & $0.561^{*}$ & 1 & & & & \\
\hline 4-Pay and Promotion Policies & $0.714^{*}$ & $0.432^{*}$ & -0.021 & 1 & & & \\
\hline $\begin{array}{l}\text { 5-Impression Management } \\
\text { (IM) }\end{array}$ & $0.608^{*}$ & $0.651^{*}$ & $0.541^{*}$ & -0.231 & 1 & & \\
\hline 6-Supervisor-focused & $0.451^{*}$ & $0.321^{*}$ & $0.651^{*}$ & $0.542^{*}$ & $0.812^{*}$ & 1 & \\
\hline 7-Self-focused & $0.652^{*}$ & -0.213 & $0.542^{*}$ & $0.342^{*}$ & $0.721^{*}$ & 0.112 & 1 \\
\hline 8-Job-focused & $0.361^{*}$ & $0.451^{*}$ & -0.110 & $0.432^{*}$ & $0.543^{*}$ & 0.231 & 0.215 \\
\hline
\end{tabular}

* Correlation is significant at the 0.05 level.

Moreover, a regression analysis was conducted and the R2 values were used to find out what amount of total change in the dependent variable was due to the independent variable dimensions. As shown in table (9), the determination factor R2was found to be 0.421 which showed that $42 \%$ of IM was dependent on POP.

Table (9): Regression Analysis

\begin{tabular}{|c|c|c|c|c|c|}
\hline Independent & \multicolumn{5}{|c|}{ Dependent variable } \\
\hline \multirow{3}{*}{$\begin{array}{c}\text { Perception of } \\
\text { organizational } \\
\text { politics }\end{array}$} & \multicolumn{5}{|c|}{ Impression Management } \\
\hline & $\beta$ & $\mathrm{T}$ & Sig. & $\mathrm{F}$ & $\mathrm{R}^{2}$ \\
\hline & .336 & 11.465 & 0.01 & 213.361 & 0.421 \\
\hline
\end{tabular}

\section{Discussion and Conclusion}

This study aimed at identifying the relationships between employees' perceptions of organizational politics and impression management behavior. The demographic profile of respondents indicated that participants were relatively young, well educated, and variants in gender. Furthermore, the results of this study revealed that male employees perceived organizational politics more than female. The same results are also valid for impression management behaviors. Another significant result of the current study was that employees who were between 31- 40 ages had a higher IM and POP than other age groups. Also, it was found that those having 6-10 years of experience have largely participated in IM and POP. 
Based on the questionnaire results, the researchers found that the perceptions of organizational politics included three factors: General Political Behavior, Go Along to Get Ahead, and Pay and Promotion Policies. All the three factors have positive impact and correlated with IM except pay and promotion policies. Therefore, employees who understand and believe that political behavior is extensive in their organization should apply impression management tactics to develop or improve his share of organizational resources and benefit. This come along with the results of (Sussman et al.,2002) study which indicated that impression management is considered as politically motivated behavior, which achieves personal goals or organizational goals.

Employees' impression management behavior included three strategies: supervisor, self-focused and Job-focused tactics, all of them demonstrate a strong and positive correlation with perception of organizational politics. Moreover, IM behavior was positively correlated with POP. Results also indicated that there is a positive correlation between impression management behavior and perception of organizational politics $(r=0,608$ and $p<0.5)$, this result comes to agree with Nayyar and Raja(2012) who confirmed that there is a strong relationship between impression management and organizational politics.

According to regression analysis the determination factor was showed that $42 \%$ of IM was dependent on POP in the Egyptian travel agencies. IM has been examined as an independent variable, rather than dependent.

\section{Implication and further research}

This study merely investigates the impact of POP on impression management in travel agencies. As the relationship between an individual's POP and IM behavior has not been yet researched in tourism industry, accordingly, the current study was conducted in travel agencies and in the research IM behaviors were taken into account as a dependent variable while POP was the independent variable. There are various distinctive levels of workplace politics that eventually deliver negative outcomes. If we are to recognize that workplaces do and keep on leading inefficient outcomes, it is fundamental for travel agencies to discover approaches to diminish the negative consequences. In addition, this study likewise concentrates only on the relationship between impression management and perception of organizational politics, it leaves a scope for future researches to examine the effect of impression management on employees performance. In addition to this, future researchers shall empirically investigate the travel agencies managers' point of view of IM and POP. It would likewise be fascinating to concentrate on the negative effect of impression management. 


\section{References}

Allen, R.W., Madison, D.L. Porter, L.W. Renwick, P.A. \& Mayes, B.T. (1979). Organizational politics: Tactics and Characteristics of Its Actors. California Management Review, 22(1), 77-83.

Andrews, M.C., Witt, L.A. \& Kacmar, K.M. (2003). The interactive effect of organizational politics and exchange ideology on manager ratings of retention. Journal of Vocational Behavior, 62, 357-369. available at: http:www.ijbssnet.com/journals/Vol_5_No_8_July_2014/10.pdf (accesed on 16 May 2015).

Aryee, S., Chen, Z.X. \& Budhwar, P.S. (2004). Exchange fairness and employee performance: An examination of the relationship between organizational politics and procedural justice. Organizational Behavior and Human Decision Processes, 94, 1-14. available at: https://www.researchgate.net/file. PostFileLoader.html?id...assetKey...(Accessed on 10 May 2015).

Avery, D. R., \& McKay, P. F. (2006). Target practice: An organizational impression management approach to attracting minority and female job applicants. Personal Psychology, 59, 157 - 187.available at: https://www.ndsu.edu/.../ FinalEditReferencesonFacultyRecruitment.p... (Accessed on 10 May 2015).

Bozeman, D.P., \& Kacmar, K.M. (1997). A cybernetic model of impression management processes in organizations. Organizational Behavior and Human Decision Processes, 69, 9-30. available at: http://www.ijbssnet.com/ journals/Vol_5_No_8_July_2014/10.pdf(Accessed on 12 May 2015).

Bolino, M.C., Kacmar, K.M., Turnley, W.H. \& Gilstrap, J.B. (2008). A multilevel review of impression management motives and behaviors, Journal of Management, 34, 1080-1109 .available at: https://ou.edu/.../Management/.../ Management\%20\%20Entrepreneurs... (Accessed on 10 May 2015).

Bolino, M.C., Varela, J.A., Bande, B. \& Turnley, W.H. (2006). The impact of impression management tactics on supervisor ratings of organizational citizenship behaviour, Journal of Organizational Behavior, 27 (3), 281-297.available at: http://www.cluteinstitute.com/conference-_ proceedings/.../Article\%20245.pdf (Accessed on 12 May 2015).

Chang, D., Rosen, C., \& Levy, P. (2009). The relationship between perceptions of organizational politics and employee attitudes, strain, and behavior: A metaanalytic examination. Academy of Management Journal, 52, 779-801. available at: www.ijbssnet.com/journals/Vol_5_No_8_July_2014/10.pdf (Accessed on 12 May 2015).

Cheng, J-W., Chiu, W-L., \& Tzeng, G-H. (2013). Do impression management tactics and/or supervisor-subordinate guanxi matter? Knowledge-Based System, 40, 123-133.available at: https://ir.nctu.edu.tw/bitstream/11536 /21186/.../000315325800013.p... (Accessed on 12 May 2015). 
Cropanzano, R., Howes, J.C., Grandey, A.A. \& Toth, P. (1997). The relationship of organizational politics and support to work behaviors, attitudes, and stress. Journal of Organizational Behavior, 18, 15-180available at: https://xa.yimg.com/kq/... ISICI)1099-1379(199703)18-2-159--AID-JOB7953.0.pdf(Accessed on 12 May 2015).

Drory, A., \& Zaidman N. (2007) Impression management behavior: effects of the organizational system. Journal of Managerial Psychology, 22, 290-308available at: http//:www.scholarworks.umass.edu/cgi/viewcontent.cgi?article= 1214(Accessed on 15 May 2015)

Daskin, M. \& Tezer, M. (2012). Organizational politics and turnover: An empirical research from hospitality industry. Tourism: An International Interdisciplinary Journal, 60(3), 273-291.available at: http//:www.umkeprints.umk.edu.my I.../Conference\%20Paper\%207\%20ISEB\%2... (Accessed on 15 May 2015)

Ed. Richard A. Couto. Thousand Oaks, CA , 2010"Impression Management." Political and Civic Leadership.: SAGE. 838-48. SAGE Reference Online. Web. 30 Jan. 2012. Available at: http//:www.integral-review.org/.../vol_7_no_2 _reams_review_of_couto.pdf (Accessed15 May 2015)

Ellis, A.P., West, B.J., Ryan, A.M., \& DeShon, R.P. (2002). The use of impression management tactics in structured interviews: a function of question type? Journal of Applied Psychology. 87 (6), 1200-1208. Available at : http//www.wijzer.howest.be/wp-content/uploads/2016/02/sensitivity-to-

IM.pdf(Accessed on 12 May 2015).

Gardner, W.L. \& Martinko, M.J. (1988). Impression management in organizations, Journal of Management, 14, 321-338.availableat: https://books.google .com.eg/books?isbn=1884015190(Accessed on 15 May 2015)

Grandey, A. A. (2003). When the Show Must Go On: Surface Acting and Deep Acting as Determinants of Exhaustion and Peer-Rated Service Delivery. Academy of Management Journal, 46(1): 86-96 available at: http//:www.idjrb.com/article.pdf/article10_4m.pdf(Accessed on 15 May 2015)

Gilmore, D.C., Ferris, G. R., Dulebohn, J. H. \& Harrell-Cook, G. (1996). Organizational politics and employee attendance.Group and Organization Management, 21(4), 481-494.available at: http//:www.business.fsu. edu/docs/default-source/cob/.../gerald-ferris---vitae.pdf? (Accessed on 10 May 2015).

Goffman, E.: 1959, The Presentation of Self in Everyday Life (Garden City, Doubleday, New York).567available at: www.clockwatching.net/ jimmy/ eng101/articles/goffman_intro.pdf(Accessed on 15 May 2015)

Harris J., Kacmar, K. , Zivnuska, S., Shaw D.,(2007), The Impact of Political Skill on Impression Management Effectiveness Journal of Applied Psychology Vol. 92, No.1, 278-285567, available at www.case.edu/provost/ideal/doc/PoliticalSkill.pdf(Accessed on 10 May 2015). 
Hochwarter, W.A., and D. C.Treadway.(2003)."The Interactive Effects of Negative and Positive Affect on the Politics Perceptions-job Satisfaction Relationship." Journal of Management, 29 (4):551-567 available at: http//:www philpapers.org/archive/ABBCEO.pdf(Accessed on 25 May 2015).

Jones,E.E.(1990).Interpersonalperception.New York:Freeman.available at: http//:www.communicationcache.com/.../nonverbal_behavior_and_self-pre. (Accessed on 27 May 2015).

Judge, T.A. \& Bretz, R.D. (1994). Political influence behaviour and career success, Journal of Management, 20 (1), 43-65. available at: https://babushkabooks.com/pdf-behavior-management-slogans.html(Accessed on 27 May 2015).

Judge, T.A., Cable, D.M., Boudreau, J.W. \& Bretz, R.D. (1995). An empirical investigation of the predicators of executive career success. Personnel Psychology, 48 (3), 485-519. available at: https://babushkabooks.com/pdf-behaviormanagement-slogans.html(Accessed on 27 May 2015).

Kacmar, K.M., \& Carlson, D.S. (1997). Further validation of the perceptions of politics scale (POPS): A multiple sample investigation. Journal of Management, 23 (5), 627-658. available at: https://journals.tdl.org/ absel/index.php/absel/article/download/.../441

Kacmar, K. M., \& Ferris, G. R. (1991). Perceptions of Organizational Politics Scale (POPS): development and construct validation. Educational and Psychological Measurement, 51, 193-205.available at: https://journals.tdl.org /absel/index.php/absel/article/download/477/441(Accessed on 25 May 2015).

Liu, Y., Liu, J., \& Wu, L. (2010). Are you willing and able? Roles of motivation, power, and politics in career growth. Journal of Management, 36 (6), 1432-1460 available at: $\quad$ www.ejbss.com/Data/Sites/1/.../ejbss-1703-16culturalvaluesandcareergoal.pdf (Accessed on 27 May 2015).

Kacmar k.,Carlson,D.,1999,Effectiveness of Impression Management Tactices Across Human Resource Situation, Journal of applied social psychology,29,6,pp.1293-1315.available at: https://www.media.terry.uga.edu/socrates/publications/2015/.../Longetal2015.pdf( Accessed 24 May 2015).

Kacmar, K.M., Bozeman, D.P., Carlson, D.S. \& Anthony, W.P. (1999). An examination of the perceptions of organizational politics model: Replication and extension. Human Relations, 52(3), 383-416. available at: http://www.ijbssnet.com/journals/Vol_5_No_8_July_2014/10.pdf(Accessed on 24 May 2015).

Kenneth J. Harris,K. Michele Kacmar,Suzanne Zivnuska,Jason D. \&Shaw(2007), The Impact of Political Skill on Impression Management Effectiveness, Journal of Applied Psychology Copyright 2007 by the America.available at: http://www.case.edu/provost/ideal/doc/PoliticalSkill.pdf (Accessed on 24 May 2015). 
Leary,M.R.,\&Kowalski,R.M.(1990).Impression management:A literature review of the two component model. Psychological Bulletin,107,34-47 available at: http://wwwciteseerx.ist.psu.edu/viewdoc/download?doi=10.1.1.463. (Accessed on 25 May 2015).

Mohamed, A. A., Gardner, W. L., \& Paolillo, J. G. P. (1999). A taxonomy of organizational impression management tactics. Advances in Competitiveness Research, $\quad 7(1), \quad 108 \quad-\quad 130 .$. available 1 at: http://wwwscholarworks.umass.edu/cgi/viewcontent.cgi? article=1214\&context=gr adconf. Accessed on 25 May 2015).

Mohamed, A.A., \& Gardner, W.L. (2004). An exploratory study of interorganizational defamation: An organizational impression management perspective. Organizational Analysis, 12, 129 - 145.available at: http://wwwscholarworks.umass.edu/cgi/viewcontent.cgi?article=1214. (Accessed on 23 May 2015).

Nunnally, J. C. (1978). Psychometric theory (2nd ed.). New York, NY: McGrawHillYilmaz O., D., (2014) Perception of Organizational Politics and Impression Management Behaviors: A Tourism Industry Perspective , International Journal of Business and Social Science Vol. 5, No. 8; July 2014.available at: http://www.ijbssnet.com/journals/Vol 5_No_8 July_2014/10.pdf (Accessed on 24 May 2015).

O'Connor, W.E. and Morrison T.G. (2001). A comparison of situational and dispositional predictors of per-ceptions of organizational politics. The Journal of Psychology,135,301-12.available at: http://www. ijecm.co.uk/wpcontent/uploads/2014/06/261.pdf(Accessed on 25 May 2015).

Peeters H. , and Lievens F. (2006) Verbal and Nonverbal Impression Management Tactics in Behavior Description and Situational Interviews, INTERNATIONAL JOURNAL OF SELECTION AND ASSESSMENT VOLUME 14 NUMBER 3 SEPTEMBER 2006. Available at: http://www users.ugent.be/ flievens/im.pd(Accessed on 15 May 2015).

Poon, J.M.L. (2004). Effects of performance appraisal politics on job satisfaction and turnover intention. Personal Review, 33(3), 322-334. Available at: https://ukm.pure.elsevier.com/.../effects-of-performance-appraisal-po... (Accessed on 15 May 2015).

Rafaeli, A. \& Pratt, M. G. 1993. Tailored Meanings: On the Meaning and Impact of Organizational Dress. The Academy of Management Review, 18(1): 3355.Available at: https://web.iem.technion.ac.il/en/.../fieldclass.html?field... (Accessed on 15 May 2015).

Rosen, C., Levy, P., \& Hall, R. (2006). Placing perceptions of politics in the context of the feedback environment, employee attitudes, and job performance. The Journal of Applied Psychology, 91, 211-220. Available at: https://www.uvu.edu/woodbury/docs/organizationalpolitics.pdf (Accessed on 26 May 2015). 
SAFAY, S.,(2009), Impression Management in Consultancy: Behavior tendencies, processes, and effectiveness: Available at: https://wwwdigitalarchive. maastrichtuniversity.nl/fedora/get/guid:bbcafdcf-ecbc.../ASSET1 (Accessed on 15 May 2015).

Schlenker, B. R. \& Pontari, B. A. (2000). The strategic control of information: Impression management and self-presentation in daily life. In A. Tesser, R. Felson, \& J. Suls (Eds.), Perspectives on self and identity (pp. 199-232). Washington, DC: American Psychological Association, available at:www.psych.ufl.edu / schlenkr/im_outline.doc (Accessed on 24 May 2015).

Schniederjans, D., Cao, E.S. \& Schniederjans, M. (2013). Enhancing financial performance with social media: An impression management perspective. Decision Support Systems, 55, 911-918. available at: https:// www.ijbssnet.com/journals/Vol_5_No_8_July_2014/10.pdf (Accessed on 15 May 2015).

Stevens, C.K. and Kristof, A.L. (1995) Making the right impression: A field study of applicant impression management during job interviews. Journal of Applied Psychology, 80, 587-606.available at: https:// www doi.apa.org/journals/apl/80/5/587.pdf (Accessed on 15 May 2015)

Sussman, L., A. J. Adam, F. E. Kuzmits and L. E. Raho:2002, _Organizational Politics: Tactics, Channels, and Hierarchical Roles_, Journal of Business Ethics 40(4),313-329. ,available at: https://www.journal-archieves14.webs.com/914924.pdf (Accessed on 24 May 2015).

Tedeschi, J.T., \& Melburg, V. (1984). Impression management and influence in the organization. In S. B. Bacharach, \& E. J. Lawler (Eds.), Research in the sociology of organizations (Vol. 3, pp. 31-58). Greenwich, CT: JAI Press., available at: $\quad$ https://www.books.google.com.eg/books?isbn=0765631709 (Accessed on 24 May 2015).

Terrell, K., Kwok ,L., (2011) Organizational Impression Management Behaviors in Social Media: A Perspective of a Social Networking Site. available at: https://babushkabooks.com/pdf-behavior-management-slogans.html(Accessed on 27 May 2015).

Turnley, W. H., \& Bolino, M. C. (2001). Achieving desired images while avoiding undesired images: Exploring the role of self-monitoring in impression management.Journal of Applied Psychology, 86,351-360available at: https:// www.communicationcache.com/.../achieving_desired_images_while (Accessed on 15 May 2015)

Valle, M \& Perrewe, 2000).Do politics perceptions relate to political behaviours? Tests of an implicit assumption and expanded model. Human relations, vol., 53(3) 2 available at : https://www. irbis-nbuv.gov.ua/cgi-bin/.../cgiirbis_64.exe?.. (Accessed on 15 May 2015) 
Vigoda, E. (2000). The relationship between organizational politics, job attitudes, and work outcomes: Exploration and implications for the public sector. Journal of Vocational Behavior, 57, 326-347.available at: https://www citeseerx.ist.psu.edu/viewdoc/download?doi=10.1.1.646... (Accessed on 24 May 2015).

Vilela, b. B., González, J. A. V., Ferrín, P. F., \& del Río Araújo, M. L. 2007. Impression management tactics and affective context: influence on sales performance appraisal.European Journal of Marketing, 41(5): 624-639. available at: $\quad$ https://www.tamu.edu/faculty/.../Levy\%20\%26\%20Williams\%202004.pdf (Accessed on 24 May 2015).

Wade, K.J., \& Kinicki, A.J. (1997). Subjective applicant qualifications and interpersonal attraction as mediators within a process model of interview selection decisions. Journal of Vocational Behavior, 50, 23-40.available at : https://ir.nctu.edu.tw/bitstream/11536/14048/.../000287863500003.p...(Accessed on 26May 2015).

Wayne, S.J., \& Ferris, G.R. (1990). Influence tactics, affect, and exchange quality in supervisor-subordinate interactions: a laboratory experiment and field study. Journal of Applied Psychology, 75, 487-499. available at: https://wwwdoi.apa.org/journals/apl/75/5/487.pdf

Wayne, S.J. \& Liden, R.C. (1995). Effects of impression management on performance ratings: a longitudinal study. Academy of Management Journal, 38 (1), 232-260. Available at: https://www.study.huizhou.gov.cn/lessionnew /bdmpa/MPA-B05/.../thes04_1.pdf (Accessed on 26May 2016).

Yilmaz, O. D.,(2014) Perception of Organizational Politics and Impression Management Behaviors: A Tourism Industry Perspective, International Journal of Business and Social Science, Vol. 5, No. 8; July 2014 Available at: https://www ijbssnet.com/journals/Vol_5_No_8_July_2014/10.pdf

ZIVNUSKA, S. , KACMAR, M. , WITT A. , CARLSON, S. \&BRATTON, K. (2004),Interactive effects of impression management and organizational politics on job performance, Journal of Organizational Behavior. Available at: http://onlinelibrary.wiley.com/doi/10.1002/job.262/pdf Accessed on 26May 2016). 


\section{العلاقة بين إدارة الانطباع والسياسات التنظيمية في شركات السياحة المصرية}

$$
\text { الملخص العربي }
$$

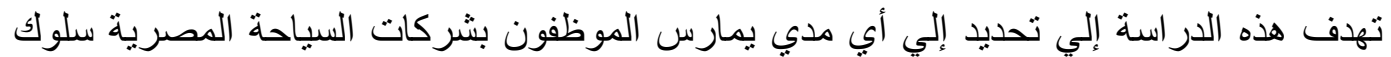

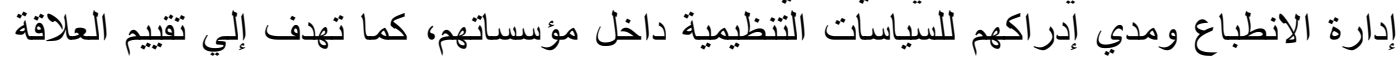

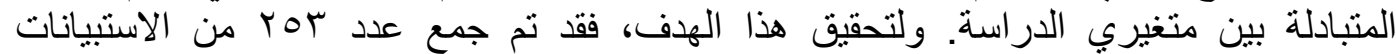

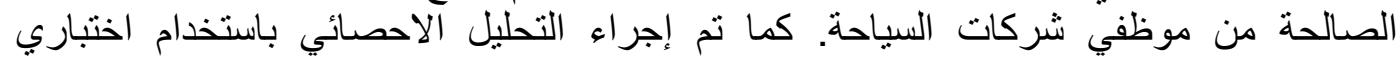

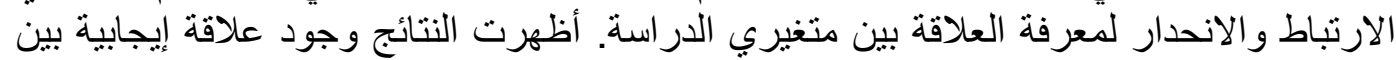

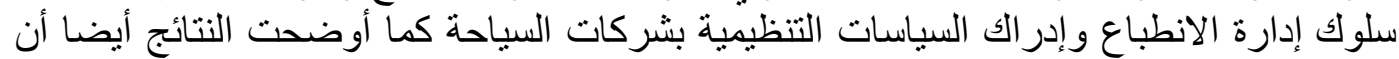

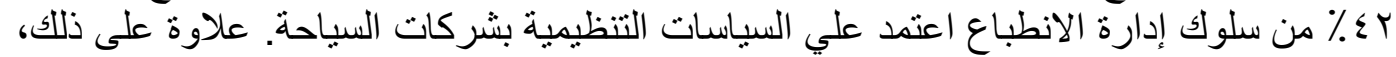

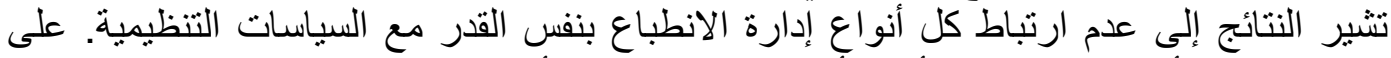

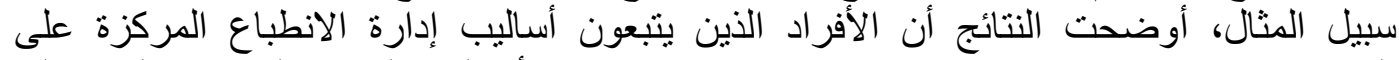

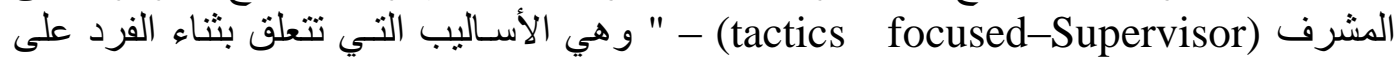

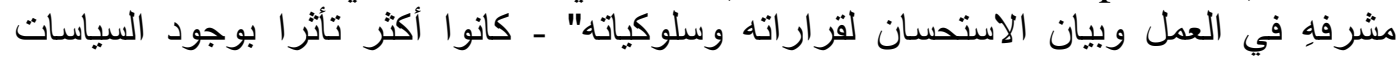
التنظيمية من الأفر اد الذين يتبعون الأساليب المركزة على العمل (job focused -tactics ). 